\title{
Cytochrome P450 2E1
}

National Cancer Institute

\section{Source}

National Cancer Institute. Cytochrome P450 2E1. NCI Thesaurus. Code C16485.

Cytochrome P450 2E1 (493 aa, 57 kDa) is encoded by the human CYP2E1 gene. This protein plays a role in the both the metabolism of drugs, ethanol and other xenobiotics and the oxidative activation of nitrosamines. 